\title{
Floral Initiation in Pharbitis nil Subjected to Continuous Illumination at Relatively Low Temperatures II. Effect of Some Factors in Culture Medium on Floral Initiation
}

\author{
by Kazuyoshi KImuRA*
}

Received August 19, 1963

It has been reported in the previous papers ${ }^{1-2)}$ that Pharbitis nil initiated floral primordia under continuous illumination at relatively low temperatures. Optimal flowering was observed when the plants were maintained on sucrose medium at $15^{\circ}$ for 30 days.

The present experiments were performed in order to examine the effect of various cultural conditions on floral initiation of Pharbitis nil plants grown aseptically under continuous illumination at $15^{\circ}$

\section{Material and Methods}

The strain "Violet" of Pharbitis nil was used as the experimental material. Unless otherwise mentioned, the basic culture medium was a modified White's solution. It contains: $200 \mathrm{mg} \mathrm{Ca}\left(\mathrm{NO}_{3}\right)_{2}, 360 \mathrm{mg} \mathrm{MgSO}_{4}, 200 \mathrm{mg} \mathrm{Na} \mathrm{SO}_{4}, 80 \mathrm{mg} \mathrm{KNO}_{3}$, $65 \mathrm{mg} \mathrm{KCl}, 16.5 \mathrm{mg} \mathrm{NaH} \mathrm{PO}_{4}, 4.5 \mathrm{mg} \mathrm{MnSO}_{4}, 1.5 \mathrm{mg} \mathrm{ZnSO}, 0.75 \mathrm{mg} \mathrm{KI}, 4 \mathrm{mg} \mathrm{Fe}-$ citrate, $8 \mathrm{~g}$ agar and $1000 \mathrm{ml}$ dist. water. The medium was placed in test tubes and autoclaved at $1.5 \mathrm{~kg} / \mathrm{cm}^{2}$ overpressure for 15 minutes.

The experimental methods employed for seed sterilization and sowing were similar to those reported in a previous paper ${ }^{1}$.

All the plants were grown under continuous illumination from daylight fluorescent lamps, the luminosity of which was from 1500 to 2000 lux at the plant level. They were kept at $15^{\circ}$ for 30 days, and then at $25^{\circ}$ for an additional 15 days, at the end of which time they were dissected for the observation of floral initiation.

Control plants were exposed to continuous illumination at $25^{\circ}$ and observed 45 days after germination. Controls did not initiate floral primordia in any of the experiments and have been omitted from the following summary tables.

\section{Results}

1. Effect of agar concentration: The effects of varying concentrations of agar added to the basal medium containing either $5 \%$ or no sucrose on the flowering and growth of the plants are shown in Table 1. Better growth was caused with 0.75 or $1 \%$ than with other agar concentrations. The culture medium with $0.3 \%$ agar is fluid and those with $1.5 \%$ and $2 \%$ are solid in consistency. On such media the plants grew poorly. Dry weight of plants grown on media with 5\% sucrose was significantly heavier than that of plants grown on media without sucrose, but no significant differences in fresh weight and shoot length were found between the

* Laboratory of Applied Botany, Faculty of Agriculture, Kyoto University, Kyoto, Japan Present address: The Ohara Institute for Agricultural Biology, Okayama University, Kurashiki, Japan. 
Table 1. Effect of agar concentrations on floral initiation and growth in Pharbitis nil subjected to continuous illumination at $15^{\circ}$ for 30 days.

\begin{tabular}{c|c|c|c|c|c|c|c}
\hline $\begin{array}{c}\text { Sucrose } \\
\text { conc. } \\
(\%)\end{array}$ & $\begin{array}{c}\text { Agar } \\
\text { conc. } \\
(\%)\end{array}$ & $\begin{array}{c}\text { No. of } \\
\text { plants }\end{array}$ & $\begin{array}{c}\text { \% of } \\
\text { plants with } \\
\text { flower buds }\end{array}$ & $\begin{array}{c}\text { No. of } \\
\text { fower buds } \\
\text { per plant }\end{array}$ & $\begin{array}{c}\text { Shoot } \\
\text { length } \\
\text { in mm }\end{array}$ & $\begin{array}{c}\text { Fresh } \\
\text { weight } \\
\text { in mg }\end{array}$ & $\begin{array}{c}\text { Dry } \\
\text { weight } \\
\text { in mg }\end{array}$ \\
\hline \multirow{5}{*}{0} & 0.3 & 13 & 0 & 0 & 8.0 & 242.0 & 24.0 \\
& 0.75 & 13 & 0 & 0 & 23.2 & 434.0 & 25.0 \\
& 1.0 & 14 & 0 & 0 & 17.1 & 286.5 & 23.1 \\
& 1.5 & 3 & 0 & 0 & 16.4 & 260.0 & 22.3 \\
& 2.0 & -+ & - & - & - & - & - \\
\hline & 0.3 & 13 & 38.5 & 1.7 & 10.0 & 283.7 & 43.3 \\
& 0.75 & 15 & 100 & 5.0 & 22.6 & 430.0 & 63.8 \\
& 1.0 & 14 & 85.7 & 3.9 & 18.0 & 341.2 & 54.8 \\
& 1.5 & 13 & 43.4 & 0.7 & 15.6 & 271.2 & 40.3 \\
& 2.0 & 12 & 33.3 & 1.0 & 15.1 & 257.0 & 39.0 \\
\hline
\end{tabular}

$\uparrow$ All plants died.

plants grown on media with and without sucrose. None of the plants cultured on sucrose-free media initiated floral primordia. The maximum promotion of flowering occurred on sucrose media containing 0.75 or $1 \%$ agar, only a few plants initiating floral primordia on media with $0.3 \%$ or 1.5 and $2 \%$ agar.

2. Effect of $p H$ : The $\mathrm{pH}$ values were adjusted before autoclaving by the addition of $1 \mathrm{~N}-\mathrm{HCl}$ and $1 \mathrm{~N}-\mathrm{Na}_{2} \mathrm{CO}_{3}$, using glass electrodes for their determinations. As shown in Table 2, at $\mathrm{pH} 3.59$ the growth of the plants was inhibited strikingly

Table 2. Effect of $\mathrm{pH}$ of the medium containing $5 \%$ sucrose. The plants were cultured under continuous illumination at $15^{\circ}$ for 30 days. The $\mathrm{pH}$ values were adjusted with $1 \mathrm{~N}-\mathrm{HCl}$ and $1 \mathrm{~N}-\mathrm{Na}_{2} \mathrm{CO}_{3}$ before autoclaving.

\begin{tabular}{c|c|c|c|cc}
\hline \multicolumn{2}{c|}{ pH values } & No. of & $\begin{array}{c}\% \text { of } \\
\text { plants with } \\
\text { flants } \\
\begin{array}{c}\text { Before } \\
\text { flower buds }\end{array}\end{array} \begin{array}{c}\text { After } \\
\text { autoclaving }\end{array}$ & $\begin{array}{c}\text { No. of } \\
\text { flower buds } \\
\text { per plant }\end{array}$ & $\begin{array}{c}\text { Shoot } \\
\text { length } \\
\text { in mm }\end{array}$ \\
\hline 3.01 & 3.59 & 3 & 0 & 0 & 8.6 \\
4.21 & 4.32 & 18 & 100 & 4.2 & 28.8 \\
$5.22 \dagger$ & 5.02 & 16 & 100 & 4.1 & 28.0 \\
6.22 & 5.50 & 16 & 87.5 & 2.3 & 26.6 \\
6.98 & 5.92 & 15 & 73.3 & 2.1 & 22.9 \\
8.85 & 6.86 & 16 & 75.0 & 1.8 & 20.6 \\
\hline
\end{tabular}

† Original $\mathrm{pH}$ value of White's solution without adjustment.

and almost all of them died probably because of the fluid and strong acidic conditions of the medium at this $\mathrm{pH}$ level. The plants grew fairly well and developed flowers on the media with $\mathrm{pH}$ values ranging from 4.32 to 6.86 . Most of the plants initiated floral primordia on sucrose media, the $\mathrm{pH}$ values of which ranged from 4.32 to 5.50 . At pHs 5.92 and 6.86, the percentages of flowering plants were 73.3 and 75.0 , respectively.

3. Effect of mineral nutritions: In order to examine the effect of nutritive 
components, the following series of culture media were used. A, $0.8 \%$ plain agar; MA, minerals $+0.8 \%$ agar; $\mathrm{SA}, 5 \%$ sucrose $+0.8 \%$ agar; $\mathrm{MSA}$, minerals $+5 \%$ sucrose $+0.8 \%$ agar.

The results of the experiment are presented in Table 3. Shoot length and fresh

Table 3. Effect of minerals and sucrose in the media. The plants were cultured under continuous illumination at $15^{\circ}$ for 30 days. A, $0.8 \%$ plain agar; MA, minerals $+0.8 \%$ agar; SA, $5 \%$ sucrose $+0.8 \%$ agar; MSA, minerals $+5 \%$ sucrose $+0.8 \%$ agar.

\begin{tabular}{c|c|c|c|c|c|c}
\hline $\begin{array}{c}\text { Components of } \\
\text { culture media }\end{array}$ & $\begin{array}{c}\text { No. of } \\
\text { plants }\end{array}$ & $\begin{array}{c}\text { \% of } \\
\text { plants with } \\
\text { flower buds }\end{array}$ & $\begin{array}{c}\text { No. of } \\
\text { flower buds } \\
\text { per plant }\end{array}$ & $\begin{array}{c}\text { Shoot } \\
\text { length } \\
\text { in mm }\end{array}$ & $\begin{array}{c}\text { Fresh } \\
\text { weight } \\
\text { in mg }\end{array}$ & $\begin{array}{c}\text { Dry } \\
\text { weight } \\
\text { in }\end{array}$ \\
\hline A & 22 & 0 & 0 & 15.1 & 300 & 22.2 \\
MA & 24 & 0 & 0 & 17.3 & 421.0 & 25.0 \\
SA & 18 & 100 & 4.0 & 15.9 & 295.4 & 50.0 \\
MSA & 21 & 100 & 3.7 & 22.7 & 461.3 & 60.5 \\
\hline
\end{tabular}

weight showed relatively higher values on MA and MSA media, which both contained minerals, but dry weight showed higher values on media containing sucrose, SA and MSA. On media containing sucrose, floral primordia were initiated whether the minerals were added or not, indicating that mineral nutrients from the seed and agar were sufficient for the limited growth of this plant.

4. Effect of carbon-nitrogen ratios: Agar media containing $0,1,2$ or $5 \%$ sucrose and $0,0.05,0.1$ or $0.5 \% \mathrm{KNO}_{3}$ (without the other minerals of White's solution) were used for examination of the effect of the carbon-nitrogen ratio on floral initiation. The results of the experiment are presented in Tables 4 and 5. Shoot length showed maximum values on media containing $0.05 \% \mathrm{KNO}_{3}$ irrespective of concentrations of sucrose added together, and relatively high values were obtained on $1 \%$ and $2 \%$ sucrose media containing $0.1 \% \mathrm{KNO}_{3}$. Although media with $0.05-0.1 \% \mathrm{KNO}_{3}$ caused an increase in shoot length, they were unfavourable for flowering. On media containing $1 \% \mathrm{KNO}_{3}$ (although the results were omitted from Table 4 and 5), the growth was quite retarded at all sucrose concentrations and floral initiation did not occur. Plants remained vegetative on sucrose-free media whether $\mathrm{KNO}_{3}$ was added

Table 4. Effect of sucrose- $\mathrm{KNO}_{3}$ ratios on floral initiation. Plants were cultured under continuous illumination at $15^{\circ}$ for 30 days. The flowering response in each medium is given as the percentage of plants with flower buds. The number of plants observed is given in parentheses.

\begin{tabular}{c|c|c|c|c}
\hline \multirow{2}{*}{$\begin{array}{c}\text { Sucrose conc. } \\
(\%)\end{array}$} & \multicolumn{4}{|c|}{$\mathrm{KNO}_{3}$ concentration (\%) } \\
\cline { 2 - 5 } & 0 & 0.05 & 0.1 & 0.5 \\
\cline { 2 - 4 } 0 & 0 & 0 & 0 & 0 \\
& $(12)$ & $(16)$ & $(14)$ & $(11)$ \\
& 50.0 & 14.3 & 25.0 & 52.9 \\
& $(16)$ & $(21)$ & $(20)$ & $(17)$ \\
& 72.8 & 21.8 & 59.2 & 70.0 \\
5 & $(22)$ & $(23)$ & $(22)$ & $(20)$ \\
& 94.5 & 70.1 & 95.0 & 87.5 \\
& $(18)$ & $(20)$ & $(20)$ & $(16)$ \\
\hline
\end{tabular}


Table 5. Shoot length $(\mathrm{mm})$ on media with various sucrose- $\mathrm{KNO}_{3}$ ratios. Plants were subjected to continuous illumination at $15^{\circ}$ for 30 days.

\begin{tabular}{c|c|c|c|c}
\hline \multirow{2}{*}{$\begin{array}{c}\text { Sucrose conc. } \\
(\%)\end{array}$} & \multicolumn{3}{|c}{$\mathrm{KNO}_{3}$ concentration (\%) } \\
\cline { 2 - 4 } & 0 & 0.05 & 0.1 & 0.5 \\
\hline 0 & 21.8 & 58.5 & 33.1 & 27.0 \\
1 & 33.5 & 75.1 & 53.3 & 26.9 \\
2 & 35.9 & 74.3 & 47.2 & 33.1 \\
5 & 25.6 & 52.1 & 35.1 & 23.8 \\
\hline
\end{tabular}

or not. It seems that floral initiation under continuous illumination at a relatively low temperature may result from conditions causing poor vegetative growth, but the reproductive development appears to be inhibited when the growth is inhibited strikingly.

To investigate further the influence of the " $\mathrm{C}-\mathrm{N}$ " ratio on flowering, $\mathrm{Ca}\left(\mathrm{NO}_{3}\right)_{2:}$ in place of $\mathrm{KNO}_{3}$ was added to agar media with $2 \%$ sucrose (Table 6). On the media

Table 6. Effect of $\mathrm{Ca}\left(\mathrm{NO}_{3}\right)_{2}$ concentrations on floral initiation and growth in Pharbitis nil. Plants were grown under continuous illumination at $15^{\circ}$ on media containing $2 \%$ sucrose for 30 days.

\begin{tabular}{|c|c|c|c|c|}
\hline$\underset{(\%)}{\mathrm{Ca}\left(\mathrm{NO}_{3}\right)_{2}}$ conc. & No. of plants & $\begin{array}{l}\% \text { of plants with } \\
\text { flower buds }\end{array}$ & $\begin{array}{l}\text { No. of flower } \\
\text { buds per plant }\end{array}$ & $\begin{array}{l}\text { Shoot length } \\
\text { in } \mathrm{mm}\end{array}$ \\
\hline 0 & 23 & 73.9 & 3.5 & 47.6 \\
\hline 0.05 & 20 & 45.0 & 2.4 & 61.4 \\
\hline 0.1 & 23 & 65.3 & 2.7 & 60.1 \\
\hline 0.2 & 20 & 80.0 & 3.8 & 35.9 \\
\hline
\end{tabular}

containing 0.05 or $0.1 \% \mathrm{Ca}\left(\mathrm{NO}_{3}\right)_{2}$, shoot length showed higher values, but the flowering response was suppressed. These results are similar to those obtained in the above experiment with $\mathrm{KNO}_{3}$.

5. Effect of sucrose concentration: The effect of sucrose concentration in the medium on floral initiation and growth is shown in Table 7. Shoot length showed

Table 7. Effect of sucrose concentration on floral initiation and growth. Plants were subjected to continuous illumination at $15^{\circ}$ for 30 days.

\begin{tabular}{c|c|c|c|c|c|c|c}
\hline $\begin{array}{c}\text { Sucrose } \\
\text { conc. } \\
(\%)\end{array}$ & $\begin{array}{c}\text { No. of } \\
\text { plants }\end{array}$ & $\begin{array}{c}\% \text { of } \\
\text { plants with } \\
\text { flower buds }\end{array}$ & $\begin{array}{c}\text { No. of } \\
\text { flower buds } \\
\text { per plant }\end{array}$ & $\begin{array}{c}\text { \% of plants } \\
\text { with terminal } \\
\text { flower buds }\end{array}$ & $\begin{array}{c}\text { Shoot } \\
\text { length } \\
\text { in mm }\end{array}$ & $\begin{array}{c}\text { Fresh } \\
\text { weight } \\
\text { in mg }\end{array}$ & $\begin{array}{c}\text { Dry } \\
\text { weight } \\
\text { in mg }\end{array}$ \\
\hline 0 & 14 & 0 & 0 & 0 & 17.5 & 421.0 & 25.0 \\
1 & 16 & 50.0 & 1.2 & 50.0 & 21.8 & 443.0 & 41.0 \\
2 & 19 & 79.0 & 2.6 & 79.0 & 22.1 & 492.2 & 47.0 \\
4 & 19 & 100 & 4.1 & 100 & 24.5 & 460.7 & 52.3 \\
6 & 15 & 100 & 3.5 & 100 & 18.4 & 448.5 & 64.5 \\
8 & 16 & 100 & 3.0 & 100 & 15.6 & 446.7 & 78.6 \\
10 & 17 & 100 & 2.9 & 100 & 15.1 & 325.5 & 70.5 \\
\hline
\end{tabular}


higher values on media 1-4\% sucrose. Fresh weight was nearly the same in all lots, except for a somewhat lower value in the medium containing $10 \%$ sucrose. The dry weight of plants grown on sucrose medium was 2 to 3 times greater than that on sucrose-free medium and increased with increasing sucrose concentrations.

Floral initiation was not observed when the plants were grown in a sucrose-free medium. All plants initiated floral primordia and terminal flower buds on media with sucrose at concentrations from 4 to $10 \%$. However, the number of flower buds per plant was largest in plants grown on the medium containing $4 \%$ sucrose.

6. Effect of various sugars: Table 8 shows the effect of different sugars

Table 8. Effect of various sugars on floral initiation and growth. Plants were subjected to continuous illumination at $15^{\circ}$ for 30 days.

\begin{tabular}{l|c|c|c|c|c|c}
\hline $\begin{array}{c}\text { Sugars } \\
(0.15 \mathrm{M})\end{array}$ & $\begin{array}{c}\text { No. of } \\
\text { plants }\end{array}$ & $\begin{array}{c}\text { \% of } \\
\text { plants with } \\
\text { flower buds }\end{array}$ & $\begin{array}{c}\text { No. of } \\
\text { flower buds } \\
\text { per plant }\end{array}$ & $\begin{array}{c}\text { Shoot } \\
\text { length } \\
\text { in mm }\end{array}$ & $\begin{array}{c}\text { Fresh } \\
\text { weight } \\
\text { in mgt }\end{array}$ & $\begin{array}{c}\text { Dry } \\
\text { weight } \\
\text { in mgt }\end{array}$ \\
\cline { 1 - 4 } Sugar-free & 14 & 0 & 0 & 22.7 & 328.6 & 34.6 \\
Xylose & 16 & 6.3 & 0.1 & 13.9 & - & - \\
Galactose & 12 & 0 & 0 & 11.1 & 210.7 & 43.2 \\
Glucose & 15 & 66.6 & 2.2 & 23.8 & 282.1 & 47.6 \\
Fructose & 23 & 100 & 3.1 & 29.8 & 335.6 & 53.7 \\
Mannose & 17 & 100 & 3.7 & 19.1 & 235.8 & 55.1 \\
Mannitol & 9 & 11.1 & 0.7 & 15.4 & 179.1 & 40.8 \\
Sucrose & 23 & 100 & 4.0 & 32.0 & 376.3 & 62.3 \\
Maltose & 19 & 100 & 4.4 & 32.0 & - & - \\
Lactose & 20 & 90.0 & 4.3 & 31.3 & 305.7 & 48.8 \\
Raffinose & 19 & 100 & 3.9 & 35.9 & - & - \\
Starch & 18 & 0 & 0 & 21.0 & - & - \\
(soluble 5\%) & 10 & & & & & - \\
\hline
\end{tabular}

$\uparrow-$, not observed.

$(0.15 \mathrm{M})$ on floral initiation and growth. The plants grown on media containing xylose, galactose, mannose, mannitol or soluble starch, as compared with those grown on media without sugars, showed lower values in shoot length and fresh weight. Dry weight increased on all media containing sugars. Fructose, mannose, sucrose, maltose, lactose and raffinose were found to be very effective in causing floral initiation. Only $66 \%$ of plants cultured on glucose medium initiated floral primordia. Xylose and mannitol were less effective, and galactose, and soluble starch had no effect.

In another experiment, five effective sugars, glucose, fructose, mannose, maltose and sucrose, were sterilized by filtrating through a Seitz filter and added aseptically to the autoclaved basal medium. The sugar concentration was $0.15 \mathrm{M}$ (Table 9).

The above sugars sterilized by Seitz filtration were as effective as the autoclaved sugars in causing floral initiation. The present glucose, however, gave somewhat higher percentage of flowering plants than the autoclaved glucose.

7- Effect of time and duration of sucrose supply: From the experiments mentioned above and those reported previously ${ }^{1)}$, it is noticed that sucrose added to the medium was effective in causing floral initiation of plants under continuous allumination if applied at low temperatures. In these experiments, sucrose was 
Table 9. Effect of various sugars sterilized with Seitz-filter on floral initiation. Plants were subjected to continuous illumination at $15^{\circ}$ for 30 days.

\begin{tabular}{l|c|c|c|c}
\hline $\begin{array}{c}\text { Sugars } \\
(0.15 \mathrm{M})\end{array}$ & $\begin{array}{c}\text { No. of } \\
\text { plants }\end{array}$ & $\begin{array}{c}\% \text { of } \\
\text { plants with } \\
\text { flower buds }\end{array}$ & $\begin{array}{c}\text { No. of } \\
\text { flower buds } \\
\text { per plant }\end{array}$ & $\begin{array}{c}\% \text { of plants } \\
\text { with terminal } \\
\text { flower bud }\end{array}$ \\
\hline Glucose & 15 & 80.1 & 3.7 & 80.1 \\
Fructose & 16 & 87.5 & 4.2 & 87.5 \\
Mannose & 15 & 93.4 & 4.5 & 93.4 \\
Maltose & 16 & 93.8 & 4.6 & 93.8 \\
Sucrose & 17 & 100 & 4.7 & 100 \\
\hline
\end{tabular}

Table 10. Effect of time and duration of sucrose application. Plants were cultured at $15^{\circ}$ for 30 days and then at $25^{\circ}$ for 15 days under continuous illumination.

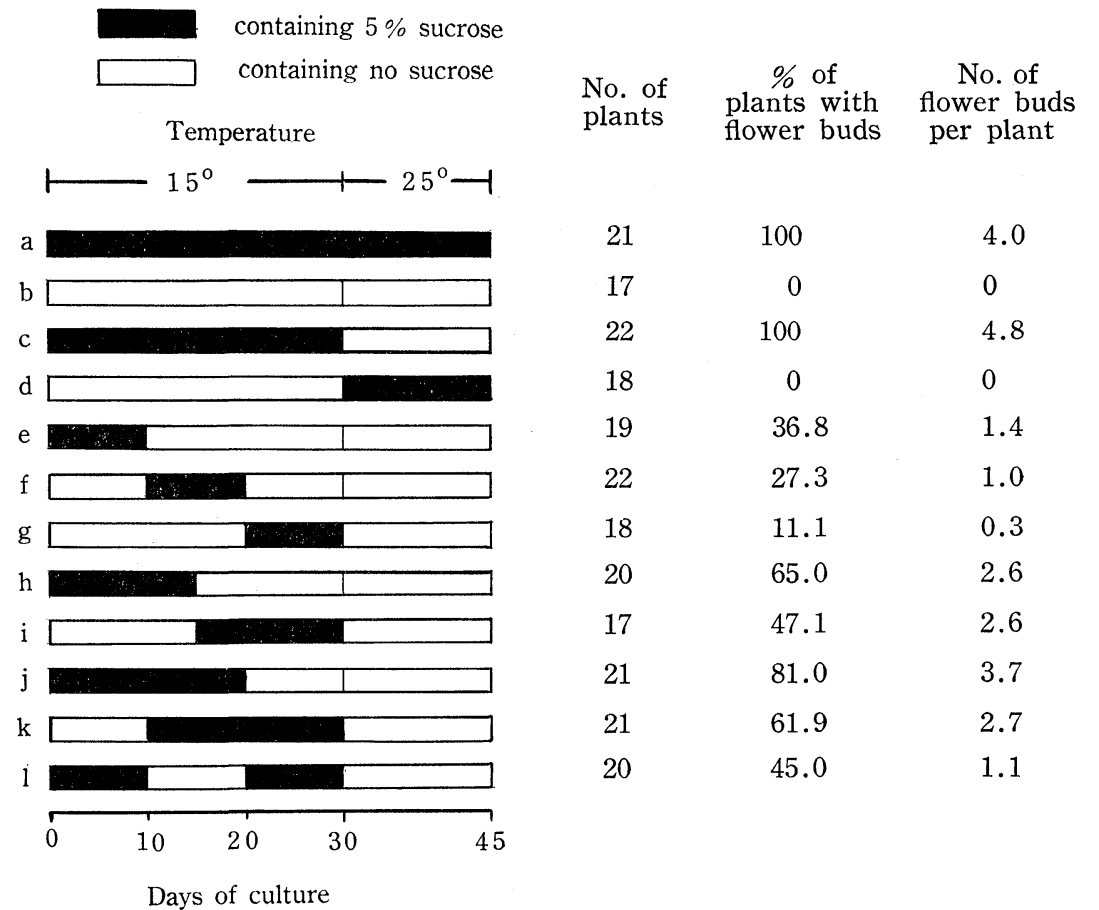

supplied to the plants throughout the experimental period. The present experiment: is concerned with the effect of sucrose $(5 \%)$ which is given for various days at different times of the experimental period. The results are presented in Table 10.

In lots $\mathrm{a}$ and $\mathrm{c}$, in which $5 \%$ sucrose was applied during the low-temperature treatment or throughout the experimental period, all of the plants initiated floral primordia. However, in lots $b$ and $d$, in which sucrose was supplied after the lowtemperature treatment or not supplied throughout the experimental period, floral primordia were not initiated. The presence or absence of sucrose after the end of the low-temperature treatment had no influence on floral initiation: sucrose was. effective for floral initiation only when supplied during the low-temperature treatment. 
of $15^{\circ}$.

Comparing the lots of $\mathrm{c}, \mathrm{e}, \mathrm{h}$ and $\mathrm{j}$, in which sucrose was supplied from the start of the experiment, the flowering percentages increased in the following order: $\mathrm{e}<\mathrm{h}<\mathrm{j}<\mathrm{c}$. The percentages of flowering increased with increasing duration of sucrose application. From the comparison among the lots of $\mathrm{e}, \mathrm{f}$ and $\mathrm{g}$, between $\mathrm{h}$ and $\mathrm{i}$, or between $\mathrm{j}$ and $\mathrm{k}$, it was found that sucrose given in the earlier phases of the low-temperature treatment was more effective for floral initiation than that given in the later phases.

\section{Discussion}

Under conditions of restricted growth, as is the case with the present in vitro experiment, sucrose supplied to the medium promotes floral initiation to a great extent.1,2) Optimal flowering responses were observed when the plants were cultured on sucrose $(4-10 \%)$ media containing 0.75 or $1 \%$ agar and on the media of $\mathrm{pH}$ values ranging from 4.32 to 5.50 (Table 1,2 and 7). One may assume that the reduced flowering response of plants cultured with 0.3 (fluid medium), 1.5 or $2 \%$ agar (stiff medium), or at $\mathrm{pH} 3.59$ (fluid medium), is due to the poor growth.

On the medium containing sucrose, floral primordia were initiated without addition of mineral elements. Some workers ${ }^{3-5)}$ have suggested that the ratio of carbohydrate to nitrogen or nitrogen nutrition plays an important role in the control of flowering. In general, the flowering percentage of plants in the present experiment increased with increasing sucrose concentration. On the media containing $0.05-0.1 \% \mathrm{KNO}_{3}$ or $\mathrm{Ca}\left(\mathrm{NO}_{3}\right)_{2}$, shoot growth was promoted, but flowering responses were reduced. It seems that floral initiation under continuous illumination at $15^{\circ}$ is also correlated, to some extent, to the poor vegetative growth.

Steinberg ${ }^{6)}$ studied the effect of various organic substances on the floral initiation of Nicotiana rustica in vitro. His results indicated that sugars such as sucrose promoted flowering. Gregory and Purvis ${ }^{7)}$ and Yamasaki ${ }^{8-10)}$ studied the effect of low temperatures on excised embryos of the cereal grains. Flowering takes place only when the embryos are vernalized on a medium containing sucrose. Yamasaki also reported that xylose, fructose, glucose, maltose and sucrose brought about some promotive effect in vernalization. The effect of vernalization increased with increasing length of the period during which embryo and endosperm coexisted, and this coexistence was more effective in the earlier term than in the later term during the low temperature treatment. They believed that carbohydrates were required during vernalization, presumably as an energy source for the process.

In the present experiments, glucose, fructose, mannose, sucrose, maltose, lactose and raffinose added to the medium were effective in causing floral initiation, but xylose, galactose, mannitol and soluble starch were not (Table 8). Sucrose was effective when supplied during the period of low-temperature treatment at $15^{\circ}$. Carbohydrate source, therefore, plays an important role during the low-temperature treatment. As in the case of vernalization of cereal plants, sucrose was more effective for the promotion of flowering when given during the early portion than when given during the late portion of the period at $15^{\circ}$ (Table 10). Whether there is any difference in the mode of action of low temperatures in promoting flower initiation between the cases of Pharbitis and cereals, remains to be solved. 


\section{Summary}

The flowering behavior of Pharbitis nil cultured aseptically under various nutritional conditions was studied. The plants were grown under continuous illumination at a temperature of $15^{\circ}$.

1. Optimal flowering responses were observed when the plants were cultured on sucrose $(4-10 \%)$ media containing 0.75 or $1 \%$ agar and with $\mathrm{pH}$ values ranging from 4.32 to 5.50 .

2. Minerals of White's solution added to the medium had little influence in causing floral initiation; plants initiated floral primordia on agar medium containing sucrose without minerals. On sucrose media containing $0.05-0.1 \% \mathrm{KNO}_{3}$ and $\mathrm{Ca}\left(\mathrm{NO}_{3}\right)_{2}$, the flowering response was slightly suppressed. However, these media promoted vegetative growth.

3. Glucose, fructose, mannose, maltose, lactose and raffinose gave the same effective results as sucrose in causing floral initiation, but xylose, galactose, mannitol and soluble starch were less effective.

4. Sucrose was effective in promoting floral initiation when applied during the period of low-temperature treatment at $15^{\circ}$, and more effective when applied during the early part than when applied during the late part of the low-temperature period.

Grateful acknowledgment is made to Prof. S. Imamura and Dr. A. Takimoto for their suggestion and criticism.

\section{References}

1) Kimura, K., and Takimoto, A., Bot. Mag. Tokyo 76: 67 (1963). 2 2) Takimoto, A., Plant and Cell Physiol. 1: 241 (1960). $\quad 3$ ) Kraus, E.J., Am. J. Bot. 12: 510 (1925). 4) Wittwer, S.H., and Teubner, F. G., Am. J. Bot. 44: 125 (1957). 5) El Hinnary, E. I., Med. Landbouwhogeschool Wageningen 56: 1 (1956). (cited from Biol. Abstr. 32: 17486 (1958)). 6) Steinberg, R. A., Am. J. Bot. 37: 547 (1950). 7) Steinberg, R. A., Am. J. Bot. 37: 547 (1950). 7) Gregory, F. G., and Purvis, O. N., Ann. Bot. N. S. 2: 237 (1938). 8) Yamasaki, Y., Kagaku (Science) 11: 513 (1941). 9) —, ibid. 13: 159 (1943). 10) —, Agr. and Hort. 19: 989 (1944).

摘 要

木 村 和 義: 低温条件で連続光を与えたアサガオの花芽形成 II. 培養基中の三, 三の要因の花芽形成に対する影響

前報告でアサガオを低温で試験管内に培養すると連続光下でも花芽を形成することを発表した。 $15^{\circ}$, 連 続光下で 30 日間培盖されたアサガオの花芽形成に特よぼす種々の培盖基の影響を調べた。

1）ショ糖濃度 $4 \sim 10 \%, \mathrm{pH} 4.32 \sim 5.50$, 寒天濃度 $0.75 \sim 1 \%$ の培盖基が花芽分化に好適であった。

2）無機塩を含まないショ糖寒天の培養基上でも花芽を分化する。しかしショ糖を含まない寒天のみ，ぬ たは無機塩寒天の培養基上では花芽を分化しない。 $0.05 \sim 0.1 \% \mathrm{KNO}_{3}$ または $\mathrm{Ca}\left(\mathrm{NO}_{3}\right)_{2}$ を含をショ糖培 地上では生長は非常に良いが花芽分化は阻害された。

3) グルュース, フラクトース, マンノース, マルトース, ラクトース, ラフィノースはショ糖と同じく 花芽分化住效果があったが，キシロース，ガラクトース，マンニトール，デンプンは效果がなかった。

4) ショ糖は低温処理期間に培地に与兄られたとさに有効であり，低温処理後に与兄ても効果がなかっ た. また低温処理の前期に与完られた方が後期に与穴たるのより効果的であった. (岡山大学農業生物研 究所) 